\title{
O CONCEITO DE MAL EM KANT É SUFICIENTE?
}

\author{
KANT'S CONCEPT OF EVIL: IT IS ENOUGH?
}

\author{
HENRIQUE FRANCO MORITA ${ }^{1}$ \\ Universidade Federal de Santa Catarina (UFSC) - Brasil \\ henriquemorita@outlook.com
}

RESUMO: Como compreender o mal presente nos regimes totalitários? Arendt evoca o mal radical segundo Kant. Reconstrói-se, assim, a caracterização kantiana do mal. As inclinações dividem-se em afetos e paixões. Afetos são insuficientes para macular uma boa vontade, paixões afiguram-se corruptoras. Discute-se, então, a propensão para o mal e a disposição originária para o bem: a natureza humana é corrompida, mas há responsabilização. Entre natureza e arbítrio, o conceito de mal aponta para o dever de usar a liberdade de acordo com os comandos da lei moral, reconduzindo-se à disposição santa originária. Daí a ideia de que a moral conduz à religião e à plenitude da comunidade ética. Em seguida, expõe-se duas concepções de Arendt sobre o mal: I) o mal tomado no contexto do totalitarismo como mal radical, impunível e imperdoável; II) o mal tomado da perspectiva do agente, a banalidade do mal. Conclui-se, assim, que Kant não abarca a superfluidade dos seres humanos - e, portanto, a dimensão propriamente política do mal - como teorizado por Arendt, o que elucida melhor aspectos contemporâneos desse fenômeno.

PALAVRAS-CHAVE: Mal radical. Totalitarismo. Religião. Autonomia. Lei Moral.

ABSTRACT: How to understand the evil presented in totalitarian regimes? Arendt evokes radical evil as per Kant. Thus, a Kantian characterization of evil is reconstructed. Inclinations are divided into affections and passions. Affections are insufficient to tarnish a good will, while passions seem corrupting. This raises the issue of the the propensity for evil versus the original disposition for good: human nature is corrupted, but there is accountability. Between nature and agency, the concept of evil points to the duty to use freedom according to the principles of the moral law, returning to the original holy disposition. Hence the idea of morality leading to religion and to the fullness of the ethical community. Then, Arendt's two conceptions of evil are presented: I) evil taken as radical, discussed in the context of totalitarianism; II) evil taken from the perspective of the agent, the banality of evil. It follows that Kant's arguments do not cover the superfluity of human beings - nor a properly political dimension of evil - as theorized by Arendt, which elucidates the contemporary effects of this phenomenon.

KEYWORDS: Radical evil. Totalitarianism. Religion. Autonomy. Moral LaW.

\footnotetext{
${ }^{1}$ Doutorando em Filosofia pela Universidade Federal de Santa Catarina (UFSC).
} 


\section{MAL-ESTAR}

A partir dos acontecimentos traumáticos ocorridos no contexto bélico da primeira metade do século XX, o tema do mal reaparece como desafio e desilusão para o pensamento moderno. Na esteira das liberdades anunciadas pelo fim da hegemonia religiosa e a aurora da ciência e do progresso, viu-se a humanidade, principalmente no território europeu, confrontada com um cenário de guerra, violência e miséria poucas vezes experimentado de maneira tão ampla e documentada. A magnitude da morte e da dominação - inclusive com o perigo real da extinção da espécie humana em face da bomba atômica - incrustaram uma cicatriz profunda na racionalidade ocidental.

Nesse clima intelectual o pensamento de Hannah Arendt (1906 - 1975) despontou como uma tentativa de digestão e balanço desses fatos, refletindo e ao mesmo tempo construindo a narrativa do mal-estar engendrado pelo totalitarismo, cuja origem foi seu objeto de estudo na clássica obra Origens do Totalitarismo (1951). Para Arendt, o mal manifestado nesses acontecimentos não havia sido pensado anteriormente, conforme afirmou em carta a Karl Jaspers (apud BERNSTEIN, 2002, p. 19) (1883 - 1969):

[...] a tradição ocidental vem sofrendo da preocupação de que os maiores males que os seres humanos podem praticar advém do vício do egoísmo. Mas nós sabemos que o maior mal, ou o mal radical, não tem mais nada a ver com essa humanidade compreensível, esses motivos de pecado. ${ }^{2}$

O diagnóstico de Arendt em sua obra reflete a visão de que há aspectos inexplorados no fenômeno do mal da forma como ele se apresentou, por exemplo, nos regimes políticos da Alemanha nazista ou do socialismo soviético. O que há de novo e específico aqui parece estar relacionado com a desconstituição sistemática e ampla da pessoa humana considerada juridicamente, da pessoa humana considerada moralmente e, por fim, da própria feição da individualidade e dignidade humana. O aspecto mais central desse diagnóstico é a constatação da transformação do humano em algo supérfluo, o que coloca em xeque o próprio sentido da política. Hannah Arendt afirmará, então, refletindo sobre a tradição ocidental:

É inerente a toda a nossa tradição filosófica que não possamos conceber um "mal radical", e isso se aplica tanto à ideologia cristã, que concedeu ao próprio Diabo uma origem celestial, como a Kant, o único filósofo que, pela denominação que lhe deu, ao menos deve ter suspeitado de que esse mal existia, embora logo o racionalizasse no conceito de um "rancor pervertido"3 que podia ser

\footnotetext{
${ }^{2}$ Traduzido pelo autor: "[...] the Western tradition is suffering from the preoccupation that the most evil things human beings can do arise from the vice of selfishness. Yet we know that the greatest evil or radical evil has nothing to do anymore with such humanly understandable, sinful motives." ${ }^{3}$ Aqui a tradução brasileira parece se distanciar demasiadamente do original, qual seja: "[...] Kant, the only philosopher who, in the word he coined for it, at least must have suspected the existence of this evil even though he immediately rationalized it in the concept of a 'perverted ill will' that could be explained by comprehensive motives.”.
} 
explicado por motivos compreensíveis. (ARENDT, 2012, p. 510).

Nos limites desta pesquisa importa, destarte, compreender o quadro de caracterização do mal radical efetuado por Immanuel Kant (1724 - 1804), já que, como mencionado por Arendt acima, é de sua lavra a concepção desta noção. Esse intento depende de uma análise do mal radical na estrutura da filosofia moral kantiana, que se dará especialmente concentrada nas obras finais do filósofo, quais sejam a Antropologia de um ponto de vista pragmático (1798) e $A$ religião nos limites da simples razão (1793). Em seguida, procura-se mostrar como a própria Hannah Arendt compreendeu em outras bases o que ela inicialmente denomina "mal radical", passando ao conceito muito difundido de "banalidade do mal", cunhado mais tarde em sua obra.

\section{AfETOS E PAIXÕES}

O primeiro contato com a filosofia moral de Kant apresentada na Fundamentação da Metafísica dos Costumes (1785) dá a impressão de haver uma sinonímia entre a liberdade e a moralidade. A ação livre implica necessariamente uma ação moral e a única forma de equívoco moral é a ação que se deixa guiar pelas inclinações - esta é a impressão primeira. Ou seja, as inclinações levam à inobservância moral, posto serem a fraqueza do que há de inato e animal no ser humano, o que o escraviza.

No entanto, há que se perguntar se Kant, ao caracterizar os seres humanos em $A$ religião nos limites da simples razão como propensos de maneira inata para o mal e dispostos originariamente para o bem está se referindo à possibilidade de uma ação certamente livre, mas que, ao mesmo tempo, é má e contrária à lei moral, o que, por fim, envolve uma decisão voluntária e imoral. Assim expõe Maria de Lourdes Borges:

Não aprendemos com a Fundamentação que a razão nos leva necessariamente à ação moral? Ainda que o homem possa não seguir essa vontade (Wille), uma propensão ao mal parece forte demais para seres que, eventualmente, levados pelas suas inclinações, paixões e afetos, possam se desviar do caminho indicado pela lei moral. Para o leitor da obra kantiana, não restrita à Fundamentação, uma propensão para o mal parece demasiado. Mesmo para aquele que superou a incompreensão inicial possível, que nos fazia entender que toda ação livre é uma ação moral, compreende que, se ela não é necessariamente moral, a moralidade seria um ponto para o qual nossas ações convergiriam. (BORGES, 2014, p. 11).

Cumpre, portanto, investigar melhor as inclinações, concentrando-se na terceira parte da Antropologia de um ponto de vista pragmático (1798), intitulada "Da faculdade de desejar", onde a inclinação, em suas várias manifestações, é pormenorizadamente analisada. Kant desmembra as inclinações em afetos e paixões: estas, por sua vez, são analisadas pelo filósofo, na Antropologia, na parte 
em que ele trata "Dos sentimentos de prazer e desprazer". Deve-se, então, começar por tais sentimentos de prazer e desprazer, os quais dão conta de uma certa dialética do viver, que depende da dor e do prazer, do movimento e da temporalidade. As forças de prazer e desprazer, que dão contraste à vida, tem como característica o esforço de conservação (o agradável) e o esforço de mudança (a dor):

Contentamento é o sentimento de promoção da vida; dor, o de um impedimento dela. Todavia, a vida (do animal) é, como também já observam os médicos, um jogo contínuo do antagonismo entre ambos.

Assim antes de todo contentamento tem de preceder a dor, a dor é sempre o primeiro. [...].

Um contentamento tampouco pode seguir imediatamente a outro, mas, entre um e outro, tem de se encontrar a dor. [...]. A dor é o aguilhão da atividade e somente nesta sentimos nossa vida, sem esta ocorreria a ausência da vida ${ }^{4}$. (KANT, 2006, p. 128, Ak 231).

O contentamento completo, ante tal dialética, é impossível para o ser humano, seja do ponto de vista moral, com a satisfação plena de sua conduta boa (afinal, como Kant ensinou na Fundamentação nunca se tem a absoluta certeza da pureza dos móbeis de ação), seja do ponto de vista do bem-estar pragmático. A função da dor no humano é a de promover o progresso, sendo que o conceito de "completo contentamento" serve como espécie de ideia-mestra, que é perseguida, mas nunca alcançada. A posição do contentamento completo na Antropologia assemelha-se, assim (embora sirva para além do âmbito moral e político), à de Reino dos Fins (que aparece na Fundamentação) e à de Paz Perpétua (da obra homônima, de 1795):

Estar (absolutamente) saciado na vida seria repouso inerte e suspensão dos estímulos, ou embotamento das sensações e da atividade a elas ligada. Mas um estado semelhante não pode coexistir com a vida intelectual do homem, tão pouco quanto a parada do coração num corpo animal, à qual se segue inevitavelmente a morte caso não ocorra um novo estímulo (pela dor). (Ibidem, p. 130, Ak 235).

Parece ser possível depreender este mesmo sentido quando Kant discute a virtude moral na Metafísica dos Costumes (1797):

A virtude está sempre em progresso e, no entanto, está sempre começando do zero. O primeiro ponto segue-se de ela, considerada objetivamente, ser um ideal inalcançável, muito embora seja um dever aproximar-se constantemente dela. O segundo ponto funda-se, subjetivamente, na natureza humana, que é afetada por inclinações, sob a influência das quais a virtude, com suas máximas adotadas de uma vez por todas, não pode nunca pôr-se em

\footnotetext{
${ }^{4}$ Optou-se aqui por citar as obras de Kant sempre mencionando a página da tradução em português utilizada e, complementarmente, a paginação da obra de Kant segundo as obras completas editadas pela Academia de Ciências da Prússia, o que se justifica por ser a edição mais citada por comentadores ao redor do mundo. A citação com base na Academia é precedida pela sigla "Ak" e indica sempre o volume das obras completas, seguido pela paginação.
} 
tranquilidade e calma; pelo contrário, se não está em ascensão, inevitavelmente desaba, pois as máximas morais, diferentemente das técnicas, não podem ser fundadas no hábito (pois isto pertence à constituição física de sua determinação da vontade), mas, antes, mesmo se seu exercício se tornasse hábito, o sujeito com isso prejudicaria a liberdade na adoção de suas máximas, o que, porém, é o caráter de uma ação por dever. (KANT, 2013, p. 221, Ak 409).

O "completo contentamento", no campo da moral, relaciona-se ao grau de liberdade interna que o ser humano exerce quando age por dever. A liberdade interna, como Kant esclarece na Doutrina da Virtude (segunda parte da obra Metafísica dos Costumes), é própria da moralidade, enquanto a liberdade externa concerne ao âmbito jurídico-político, que cabe à Doutrina do Direito. Kant deixa bem claro os requisitos da liberdade interna:

Para a liberdade interna, entretanto, são exigidos dois elementos: ser mestre de si mesmo em um caso dado (animus sui compos) e ser senhor de si mesmo (imperium in semetipsum), isto é, domar seus afetos e dominar suas paixões (Ibidem, p. 219, Ak 407).

Os afetos e as paixões são diferentes: para os primeiros requer-se domá-los, para as últimas é preciso dominá-las. Afetos constituem uma ausência momentânea de observação da lei moral pela intensidade com que tomam o agente, provocando uma espécie de "apagão" moral. Eles são da esfera do sentimento, precedem e tornam mais difícil a reflexão racional. A falha moral que se segue desse abrupto acesso advindo dos afetos é considerada uma "ausência de virtude e, por assim dizer, algo pueril e débil, que pode muito bem coexistir com a melhor das vontades [...]" (Ibidem, p. 219, Ak 408).

A descrição dada pelo filósofo para os afetos na Antropologia remete a serem eles sentimentos de prazer ou desprazer "no estado presente, que não deixa[m] a reflexão aflorar no sujeito (a representação da razão, se se deve entregar ou resistir a ele)." (KANT, 2006, p. 149, Ak 251). Tanto quanto os afetos, também as paixões são doenças da mente na terminologia kantiana, embora tenham distintos remédios que devem ser aplicados pelo médico da mente (o próprio Kant, no caso).

As paixões são frias, se estendem no tempo, tem a feição de uma inclinação permanente, que serenou e criou raízes. O exemplo do filósofo é o de que, no caso da paixão, tem-se um sentimento de ódio, que é duradouro; enquanto no caso dos afetos tem-se a ira, que é passageira. A paixão, na sua calma racional, permite, segundo Kant afirma na Doutrina da Virtude, "acolher assim o mal (propositalmente) em sua máxima; o que, dessa maneira, é um mal qualificado, isto é, verdadeiro vício" (KANT, 2013, p. 220, Ak 408). Daí decorre, portanto, um dever de apatia, que proteja o agente de suas inclinações.

Na Antropologia Kant caracteriza as paixões como a "inclinação que a razão do sujeito dificilmente pode dominar, ou não pode dominar de modo algum". (KANT, 2006, p. 149, Ak 251). Assim, a paixão pede tempo para que perdure na 
reflexão e crie caminhos para estabelecer seus princípios de decisão para o agir guiado por ela, como máxima: "a paixão (como estado da alma pertencente à faculdade de desejar) não tem pressa e reflete para alcançar seu fim, por mais violenta que possa ser" (Ibidem, p. 150, Ak 252).

Kant recorre a diversas analogias para - seguindo seu projeto de fazer na Antropologia uma abordagem "popular" - esclarecer a diferença entre os afetos e as paixões. Aparecem, assim, os mais diversos exemplos: desde os afetos caracterizados como a água que bate contra um dique, até as paixões descritas como um rio que cava sempre mais fundo até o seu leito. O exemplo mais contundente dado pelo filósofo é o dos afetos como uma embriaguez alcoólica que leva alguém a cair no sono e a acordar no dia seguinte com a ressaca correspondente, enquanto as paixões seriam uma doença advinda da ingestão de veneno, aderente e difícil de curar: "A afecção pode ser vista como uma bebedeira que se cura dormindo; a paixão, como uma loucura que cisma com uma representação que deita raízes cada vez mais fundas" (Ibidem, p. 150-151, Ak 253.). A irracionalidade dos afetos é preferível à frieza das paixões:

As paixões estão mais proximamente relacionadas com a vontade; não obstante, isto não implica que elas possam ser trazidas ao controle da razão. Elas podem ser consideradas como uma perversão da razão, uma vez que "deitam raízes" na razão e coexistem com a decisão racional. Curiosamente, os aspectos irracionais dos afetos fazem deles preferíveis às paixões. (BORGES, 2014, p. 339). ${ }^{5}$

Paixões são faculdades sensíveis de nossa capacidade de desejar, não sendo, como os afetos, uma decorrência do objeto que nos causa algo, mas um desejo que temos pelo objeto, algo que parte de nós e não advém do objeto. A faculdade de desejar possui quatro níveis: propensão (precede à representação do objeto); instinto (desejo cego, que ainda não conhece o objeto); inclinação (desejo sensual habitual); e paixão (inclinação muito forte e enraizada, quase incontrolável). Os afetos podem impedir que o agente siga a determinação da lei moral, agindo irracionalmente, mas a paixão pode formar máximas de ação cujos princípios são reconhecidamente maus.

Os exemplos dados por Kant ao longo da Antropologia dão conta de que os seres humanos precisam estar vigilantes para fazer um adequado uso de sua racionalidade, de modo que possam disciplinar suas inclinações e fazer de seu princípio de ação aquele que a lei moral comanda. Assim, tem-se que as emoções e os sentimentos que assaltam os humanos não os tornam imputáveis per se, pois elas estão em conexão direta com características que são já dadas e reconhecidamente difíceis de domar: mas, havendo meios racionais para vencer as inclinações e fazer prevalecer o que comanda a lei moral, há, portanto, imputabilidade inescusável.

\footnotetext{
5 Traduzido pelo autor: "Passions are more closely related to the will; nevertheless, this does not imply that they can be brought under greater control by reason. They can be considered a perversion of reason, since they "take roots" into reason and coexist with rational decision. Curiously the irrational aspects of affects make it preferable to passions."
} 
Essa característica da imputabilidade individual dos agentes parece importante ao se analisar os fenômenos históricos dos totalitarismos. A ação individual nesses contextos é responsabilizável, segundo Kant, já que a consciência da lei moral não descansa nunca, nem mesmo quando se opta pela inversão das máximas morais. Mas a pergunta que continua posta é: como pode o ser humano, capaz moralmente e pleno de consciência moral, participar de um fenômeno como o Holocausto? Como é possível escolher pelo mal radical que, como tal, parece independente de escolha, encrustado na natureza humana?

\section{MAL RADICAL}

Kant inicia o texto da Religião colocando-se uma pergunta antropológica que se poderia traduzir nos seguintes termos: quais as condições de possibilidade para se atribuir ao humano uma natureza boa ou má? O filósofo esclarece que essa questão não poderia encontrar resposta empiricamente, tendo em vista chamar-se "mau a um homem não porque pratique ações que são más (contrárias à lei), mas porque estas são tais que deixam incluir nele máximas contrárias à lei” (KANT, 2008, p. 26, Ak 6:20). Máximas não se verificam senão de maneira a priori:

Assim, pois, para chamar mau a um homem, haveria que poder inferir-se de algumas ações conscientemente más, e inclusive de uma só, a priori uma máxima má subjacente, e desta um fundamento, universalmente presente no sujeito, de todas as máximas particulares moralmente más, fundamento esse que, por seu turno, é também uma máxima. (Ibidem, loc. cit.).

Oswaldo Giacóia Jr. comenta essa questão, nos seguintes termos:

Somente quando esse fundamento reside numa regra autooutorgada pelo arbítrio para regular o uso de sua liberdade é que se pode referi-la à imputabilidade; por consequência disso, tal fundamento subjetivo não pode ser outra coisa que uma máxima, isto é, um princípio inteligível de determinação da vontade, logicamente anterior a qualquer ação empírica, e que se exprime como regra geral em cuja conformidade o sujeito acolhe, como conteúdo e motivação de suas máximas concretas de ação, ou incondicionalmente a lei da moralidade, ou móveis oriundos da sensibilidade. [...].

Quanto a esse fundamento supremo, dele nada mais sabemos senão justamente que há de consistir numa máxima, pois que, dizendo respeito à regra suprema de determinação do arbítrio, não pode ser objeto de conhecimento, ou explicação, tanto quanto a própria ideia de liberdade, na medida mesmo em que só podemos conhecer aquilo que podemos derivar de uma causa segundo leis da natureza [...] (GIACOIA JR., 1998, p. 184).

Este mal deve estar fundado na liberdade do agente, e este é o sentido do termo "natureza humana" aqui empregado, não como algo dado pela animalidade. Trata-se de um ato de liberdade fundante e anterior a toda a representação 
colocada pela causalidade em face do sujeito. Dirá Kant que o mal não pode estar fundado em inclinações e impulsos naturais, ${ }^{6}$ mas sim "numa regra que o próprio arbítrio para si institui para o uso da sua liberdade, i. e., numa máxima" (KANT, 2008 , p. 27, Ak 6:21). Admite-se, portanto, a quebra do raciocínio já mencionado neste trabalho de que sempre que se age livremente se é moralmente bom. É preciso diferenciar em Kant o agir livre do agir autônomo (este sim, moral).

O arbítrio tem como característica não se sujeitar a nenhum móbil de ação, a não ser quando ele já incorporou esse móbil na forma de uma máxima. Essa máxima do arbítrio por certo que pode e deve ser a lei moral, mas não necessariamente o é, dada a espontaneidade do arbítrio, a sua liberdade. O arbítrio pode, portanto, escolher segundo móbeis diversos, mas sempre na forma da universalidade e necessidade. O ponto é que, para Kant, se a lei moral não for a determinadora do arbítrio, algo outro o fará e será contrário a ela.

Como concebe que a imputação moral ocorre apenas se se admitir o ser humano como livre (e ao mesmo tempo está buscando uma natureza de disposição de ânimo boa ou má para a humanidade), Kant precisa reafirmar os limites do conhecimento. Há uma contradição em imaginar que se possua uma essência boa ou má do humano, por um lado, mas que se lhe atribua, por outro, responsabilidade por esta característica. A junção de imputabilidade e natureza resulta problemática, e o texto kantiano sustenta essa contradição:

Ora, o fundamento subjetivo, ou a causa, desta adoção não pode, por sua vez, ser conhecido (embora seja inevitável perguntar por ele; porque se deveria, de novo, aduzir uma máxima em que se tivesse inserido esta disposição de ânimo, a qual deve, por seu turno, ter o seu fundamento). Por conseguinte, dado que não conseguimos derivar esta disposição de ânimo, ou antes o seu fundamento supremo, de qualquer primeiro actus temporal do arbítrio, apelidamola de propriedade do arbítrio, que lhe advém por natureza (embora esteja de fato fundada na liberdade). (Ibidem, p. 31, Ak 6:25).

Para o filósofo de Königsberg o ser humano possui uma disposição originária para o bem e uma propensão inata para o mal. As disposições originárias são aquilo que fazem parte da constituição humana mesma, e Kant as divide em três: animalidade, humanidade e personalidade. Esta última característica - a personalidade - é propriamente o bem moral, no sentido da "suscetibilidade da reverência pela lei moral" (Ibidem, p. 33, Ak 6:27). A raiz da personalidade é a razão prática, que conduz ao agir por dever. Como disposições originárias, as três mencionadas não podem ser dissociadas da natureza humana, sendo condição de possibilidade desta.

\footnotetext{
${ }^{6}$ Numa nota de rodapé da Religião isso está mais esclarecido: "Uma ação moralmente indiferente (adiaphoron morale) seria uma ação resultante apenas de leis da natureza, ação que, portanto, não se encontra em nenhuma relação com a lei moral enquanto lei da liberdade, porquanto não é fato algum e por não ter lugar nem ser necessário relativamente a ela nem mandamento, nem proibição, nem sequer licença (autorização legal).” (KANT, 2008, p. 29, Ak 6:23).
} 
Já a ideia de propensão para o mal aparece mais ligada à habitualidade causada pelo desejo de repetição de uma sensação experimentada de modo prazeroso. Deste desejo advém uma inclinação de que se mantenha o prazer. Lembre-se, como explicado anteriormente, que o prazer deseja conservação. A propensão para o mal, nesses termos, aparece como a possibilidade subjetiva de deflexão das leis morais, de ignorá-las e desmerecê-las. Completa Kant que "se tal propensão se pode aceitar como universalmente inerente ao homem [...], chamarse-á uma inclinação natural do homem para o mal" (Ibidem, p. 35, Ak 6:29).

Lembre-se, com Oswaldo Giacóia Jr., que o sentido de natureza é específico na Religião:

Quando se pretende refletir sobre a noção de mal radical, deve ter-se presente que temos que considerá-lo como uma propensão para o mal que tem na natureza humana sua raiz, ou melhor que se entrelaça tão inextrincavelmente com a natureza humana que se poderia dizer inato ou originário. Porém, adverte-nos Kant - para que não tropecemos desde o início nas palavras - convém lembrar que a expressão 'mal' encerra uma conotação essencialmente moral, implicando, por conseguinte, o contrário do significado usual de natureza, isto é, o domínio do determinismo causal mecânico, que se coloca em contradição com a possibilidade de se atribuir predicado moral ao agir.

A partir desse ponto de vista, o termo natureza, só pode receber uma acepção restrita, significando, pois, "O fundamento subjetivo do uso da liberdade em geral (sob leis morais) que antecede todo ato que cai nos sentidos [...]. Mas esse fundamento deve ser sempre ele mesmo um ato de liberdade [...]". (GIACOIA JR., 1998, p. 183).

Kant distingue a propensão para o mal em três graus: a fragilidade, a impureza e a malignidade. Em todas elas a consciência da lei moral está presente, a disposição originária da personalidade está lá. Porém, a fragilidade consiste na fraqueza em agir moralmente, cedendo antes da ação. Já a impureza consiste na ação em conformidade com o dever, mas baseada noutra máxima que não a lei moral. No caso da malignidade, trata-se da inversão das máximas morais por máximas más.

O agente moralmente mau, portanto, não nega a validade da lei moral. Isso não é possível, pois o ser humano sempre se vê confrontado com a moral, visto ser ela uma disposição originária. No entanto, o agente maligno toma a lei moral, para além do princípio do amor-próprio que atua misturando outros fins à lei moral, como indigna de respeito, fazendo das máximas do amor-próprio como suficientes em si mesmas, atribuindo-lhes uma dignidade. A inversão operada é a da subordinação da lei moral ao amor-próprio:

Portanto, a diferença de se o homem é bom ou mau deve residir na sua máxima (não na sua matéria), mas na subordinação (forma da máxima): de qual dos dois móbiles ele transforma em condição do outro. (KANT, 2008, p. 42, Ak 6:36). 
Tome-se aqui o emblemático exemplo trazido por Maria de Lourdes Borges (apud BORGES, 2014, p. 340), comparando um tal estado maligno (ou de malignidade) à conclamação ao mal, feita por Lady Macbeth na quinta cena do primeiro ato da peça Macbeth, de William Shakespeare:

MENSAGEIRO - Com licença, mas é verdade. Vai chegar o thane. Um dos meus camaradas a dianteira dele tomou, de estafa quase morto, mal lhe restando o fôlego preciso para dar o recado.

LADY MACBETH - Cuidem dele com carinho; traz grandes novidades.

(Sai o mensageiro.)

Rouco está o próprio corvo que crocita a chegada fatídica de Duncan à minha fortaleza. Vinde, espíritos que os pensamentos espreitais de morte, tirai-me o sexo, cheia me deixando, da cabeça até aos pés, da mais terrível crueldade! Espessai-me todo o sangue; obstruí os acessos da consciência, porque batida alguma compungida da natureza sacudir não venha minha hórrida vontade, promovendo acordo entre ela e o ato. Ao feminino peito baixai-me, e fel bebei por leite, auxiliares do crime, de onde as vossas substâncias incorpóreas sempre se acham à espreita de desgraças deste mundo. Vem, noite espessa, e embuça-te no manto dos vapores do inferno mais sombrios, porque as feridas meu punhal agudo não veja que fizer, nem o céu possa espreitar através do escuro manto e gritar: "Para! Para!"

(Entra Macbeth.)

O bem moral, nesse caso, aparece como sendo o que de mau pode ocorrer: a relação está invertida com o que comanda a lei moral, no seu fazer valer e humildar em sua santidade. Ao contrário, no aspecto da malignidade da propensão para o mal, tem-se a capacidade de considerar que o mal deve ser santificado e o bem tornado dissabor, desgraça. Kant falha, porém, em seu ônus de demonstrar como é possível ao ser humano uma natureza propensa para o mal que possa ao mesmo tempo ser objeto do uso da liberdade, de modo a implicar imputabilidade pelo mal. Parece arbitrário estabelecer que o mal é nos humanos uma inclinação constante e necessária e, ao mesmo tempo, segundo os ditames da espontaneidade do arbítrio, ser também objeto de responsabilização, tudo isso sustentando que "a prova formal de que semelhante propensão tem de estar radicada no homem podemos a nós poupá-la em vista da multidão de exemplos gritantes" (KANT, 2008, p. 38, Ak 6:33).

O mal corrompe o arbítrio, fazendo-o gestar máximas contrárias à lei moral: é um ato do arbítrio, portanto, livre. Possui, por outro lado, a característica de ser inato, independente da vontade dos seres humanos onde ele reside. Ainda assim, não se pode conceber que a propensão para o mal tenha corrompido a consciência moral, como se a lei moral, dentro da estrutura da razão, tivesse eclipsado e o ser humano enlouquecido, já que a ausência da consciência moral desfiguraria o próprio conceito de ser humano:

[...] haveria, então, uma espécie de liberdade para o mal, ou uma figura da liberdade não necessariamente ligada à lei 
suprema da moralidade, a ratio cognoscendi da liberdade. Nesse caso, o ser racional finito, que é o homem, seria praticamente indiferente em relação ao imperativo categórico. (GIACÓIA JR., 1998, p. 188).

Por esse motivo, afirma Kant:

Pensar-se como um ser que age livremente e, no entanto, desligado da lei adequada a semelhante ser (a lei moral) equivaleria a pensar uma causa que atua sem qualquer lei (pois a determinação segundo leis naturais fica excluída por causa da liberdade): o que se contradiz. (KANT, 2008, p. 41, Ak 6:35).

É importante compreender o papel que a corrupção cumpre neste ponto. Por um lado, não se pode imaginar que o mal resida simplesmente na sensibilidade, já que isso faria dele uma característica inimputável. Por outro, tampouco cabe conceber uma razão prática que se desvinculasse da lei moral, pois tal seria o caso de uma vontade diabólica, que desinteressadamente atua segundo o mal, como princípio de ação puro. O mal, portanto, ter-se-ia que situá-lo entre esses dois pontos, o que o aproxima da ideia das paixões que, friamente advindas do desejo, do amor-próprio, fincam suas raízes na racionalidade.

A boa ação moral é aquela que se dá na coincidência da matéria e da forma do arbítrio: a universalidade da lei moral. A maldade, por sua vez, consiste na corrupção adâmica dessa estrutura, com a colocação da lei do amor-próprio acima da lei moral, provocando-se a perversão da estrutura de disposição originária do ser humano, a sua vocação para a santidade:

Este é, pois, o mal radical que deve ser imputado ao homem, enquanto adâmico: radical porque corrompe o fundamento supremo de todas as máximas; e, na medida em que se encontra inextrincavelmente entrelaçado com a natureza humana, não pode ser extirpado por suas próprias forças, posto que isso não poderia ocorrer senão pela transformação da máxima suprema do arbítrio no contrário dela mesma, isto é, em virtude de esforços humanos, à disposição original para acolher a lei moral como motivo incondicional da escolha das máximas do arbítrio. (GIACÓIA JR., op. cit., p. 191).

Giacóia Jr. recorre, portanto, à ideia de pecado original com a função explicativa do desvelamento da corrupção da disposição original em relação à moralidade nos seres humanos. Sob essa perspectiva, o mundo humano é decaimento da santidade da lei moral, no sentido de que a coincidência entre a lei moral e a vontade seria, desde a Fundamentação, aquilo que caracterizaria uma vontade santa. Mas isso é vedado aos humanos, posto que nunca conseguem agir e nem ter certo para si estarem agindo com plenitude de motivos morais.

O paradoxo é que, ainda como decaídos da santidade da moralidade, os seres humanos têm o dever de combater o mal radical, que deita raízes sobre o fundamento de seus arbítrios, uma vez que são livres e, portanto, capazes de acessar a sacralidade da lei moral. É da observância ou ignorância desse ônus 
imposto pela liberdade - qual seja, a moralidade - que se pode considerar os humanos como imputáveis e responsáveis pela perseverança ou não do mau agir. Completa Giacóia Jr.:

Tal paradoxo que abre o horizonte da possibilidade para a justificação ético-teológica da confiança no auxílio da graça, tanto quanto o horizonte filosófico de reflexão sobre o sentido da história como consistindo no progresso infinito em direção ao bem e à constituição de uma comunidade ética universal, regida pela lei suprema da virtude. (Ibidem, p. 191).

Tanto na Religião quanto na Antropologia, portanto, Kant esclarece que o mal maior encontra-se em princípios racionais e não em dados empíricos da nossa natureza sensível. Na Antropologia são as paixões que realmente açoitam a moralidade num sentido racional, já que os afetos atuam de maneira repentina e causam uma cegueira moral momentânea. Na Religião é a perversão do mal radical que aparece corrompendo a disposição originária para o bem, provocando a corrupção das máximas, a inversão do princípio racional. As paixões, por sua vez, possuem ainda um caráter social:

No entanto, as paixões mais perigosas não são as inatas, mas sim as adquiridas, as que emergem da cultura. Na Religião, Kant afirma que os maus princípios da natureza humana pertencem às paixões, "que tão grandes devastações ocasionam na sua disposição originariamente boa" (Rel, AA 6:93), referindo-se principalmente às paixões sociais da sede de poder, da honra e da ganância. (BORGES, 2014, p. 343). ${ }^{7}$

Assim, para Kant a problemática do mal e a sua correspondente resolução encontram desdobramento profundo no âmbito do convívio social. Eis o que afirma na Religião, logo no início de sua terceira parte, intitulada $O$ triunfo do princípio bom sobre o mau e a fundação de um reino de Deus na Terra:

Se [o homem] buscar as causas e as circunstâncias que o arrastam para este perigo e nele o mantém, pode então facilmente convencer-se de que não procedem da sua própria natureza rude, enquanto ele existe isoladamente, mas dos homens com que está em relação ou em ligação. Não é pelos estímulos da primeira que nele se agitam as paixões, que assim importa em rigor chamar, e que tão grandes devastações ocasionam na sua disposição originariamente boa. As suas necessidades são só pequenas e o seu estado de ânimo no cuidado delas é moderado e tranquilo. Ele só é pobre (ou por tal se tem) na medida em que receia que outros homens assim o considerem e possam por isso desprezá-lo. A inveja, a ânsia de domínio, a avareza e as inclinações hostis a elas associadas assaltam a sua natureza, em si moderada, logo que se encontra no

\footnotetext{
7 Traduzido pelo autor: "However, the most dangerous passions are not innate, but the acquired ones, which arise from culture. In the Religion, Kant states that the evil principles of human nature belong to passions, "which wreak such great devastation in [human being's] originally good disposition" (Rel, AA 6:93), referring mostly to the social passions of addiction to power, addiction to honor and greed."
} 
meio dos homens, e nem sequer é necessário pressupor que estes já estão mergulhados no mal e constituem exemplos sedutores; basta que estejam aí, que o rodeiem, e que sejam homens, para mutuamente se corromperem na sua disposição moral e se fazerem maus uns aos outros. (KANT, 2008, p. 99-100, Ak 6:93).

É quando em comunidade que os seres humanos manifestam a fonte primeira da corrupção do mal radical. Aparece aí uma espécie de amor-próprio competitivo que tende a fazer prosperar o mal, se não se combatê-lo com um remédio de igual amplitude e dimensão. Nem afetos nem inclinações por si sós podem constituir a fonte do mal radical, mas tão somente as paixões que brotam do convívio entre os humanos podem sê-lo. E nem sequer faz-se necessário que os demais seres humanos sejam eles próprios eivados de maldade, mas o simples encontro das almas nessa comunidade faz com que o pior se manifeste.

Somente, portanto, um remédio social pode curar o câncer da razão prática, com o estabelecimento de uma denominada comunidade ética, uma sociedade fundada na ideia de virtude. Essa argumentação se dá no interior de uma narrativa da revolução moral do homem, que se inicia na esfera individual e se espraia para a comunidade universal. Novamente, essa revolução moral que se liga à ideia de um progresso da humanidade, advém da ideia de que a natureza do mundo, tal como desenhada por Deus nas suas disposições originárias, é boa. Mas, naquilo que se pode compreender como desdobramento da liberdade do ser humano, da sua história, ocorre a corrupção e exsurge o mal:

Ora, como é possível que um homem naturalmente mau se faça a si mesmo um homem bom, tal ultrapassa todos os nossos conceitos; pois como pode uma árvore má dar bons frutos? Mas visto que, segundo o que antes se reconheceu, uma árvore originariamente boa (quanto à disposição) produziu frutos maus, e a queda do bem para o mal (se se tiver bem em conta que esta promana da liberdade) não é mais concebível do que o ressurgimento para o bem a partir do mal, então a possibilidade desta última não pode ser contestada. [...]. Importa, sem dúvida, pressupor aqui que um gérmen do bem, que persistiu na sua total pureza, não pode ser extirpado ou corrompido, gérmen que não pode certamente ser o amor de si; tal amor, aceite como princípio de nossas máximas é precisamente a fonte de todo o mal. (KANT, 2008, p. 50-51, Ak 6:45).

Entre os comentadores, a tese de Heiner Klemme (2013) é a de que a ideia de mal radical aparece na Religião para dar possibilidade a essa noção de progresso que conduzirá da moral até a religião. Pode-se, portanto, haver recuperação individual da conexão com a lei moral na sua plenitude. Assim, novamente, são os humanos imputáveis por realizar ou não essa tarefa. A imputabilidade do ser humano está referenciada na liberdade, sendo que "não se necessita em princípio 
da doutrina do mal radical para esclarecer como é possível uma ação livre má" (KLEMME, 2013, p. 19):

A função própria do mal radical na argumentação do texto Religião fica clara se tivermos presente que "a propensão para o mal na natureza humana" (RGV, AA 6:28, t. 34) representa o maior de todos os obstáculos possíveis ao caminho da "melhoria" moral "de si mesmo" ( $R G V$, AA 6:51, t. 57). (Ibidem, p. 23).

Tendo sido a disposição originária para o bem corrompida pela propensão para o mal, deve o agente, através de uma revolução do caráter, fazer prevalecer o bem sobre o mal. Para Kant, uma vez reestabelecido o agir moral, ainda assim o perigo da propensão ao mal permanece como uma ameaça constante no horizonte. Para algo tão persistente quanto o mal radical é necessário um combate ainda mais abrangente - a comunidade ética, em que se deixa o estado considerado da individualidade moral que é aviltada a todo momento pelo contato com os demais, passando-se então ao império público da moralidade:

O homem é obrigado a deixar esse estado sem lei e se deslocar para uma "república universal segundo leis da virtude" (RGV, AA 6:98, t. 104). Enquanto com o soerguimento da sociedade civil a esperança está ligada a uma paz duradoura interna e entre estados, o soerguimento de um "ser comum ético" sob o domínio de Deus dá-nos sozinho a ocasião de ter esperança de que o bem-moral vencerá o mal moral. Não obstante a recolocação da ordem moral no âmbito dos respectivos indivíduos, que de ora avante têm uma vontade boa, no âmbito social o mal exerce seu domínio despótico sobre os homens. Para vencer, o mal sobrepõe-se às forças da vontade (virtude) dos indivíduos. [..] Donde, para superar o despotismo do mal por culpa própria, ficar uma única possibilidade: o homem deve executar um contínuo ato livre de autodeterminação, por meio do qual ele sozinho pode esperar para efetuar o que é devido moralmente em um progresso sempre duradouro: para promover o sumo bem comum ele se coloca prontamente neste mundo em uma comunidade ética. Como este fim pode ser erguido apenas da espécie humana, trata-se de um dever: "do gênero humano para consigo mesmo" (RGV, AA 6: 97, t. 103). (Ibidem, p. 26).

Esse intento de reunião na comunidade ética é, no entanto, um esforço para além dos indivíduos e só pode se dar com Deus, na religião. Assim, constitui um desdobramento da moral desenvolver-se do individual até o universal no arranjo de uma comunidade ética que está em Deus e se exprime através da religião. Heiner Klemme faz uma ponte desse progresso com a filosofia política:

Por conseguinte, as relações legais e éticas entre os homens são aquelas que se pacificam em dois passos. No âmbito da filosofia política e da do direito vale: o homem deve primeiramente deixar o estado natural e existir em uma sociedade civil; em segundo lugar ele deve aspirar ao "fim político supremo" (MSRL, AA 6: 355; t. 160) por meio da instituição de uma societas civilis segundo princípios republicanos. Diante disso, na esfera moral vale: em um primeiro passo, o homem deve restituir a ordem moral, e 
como, com isso, ainda o estado ético natural não é superado, ele deve em segundo lugar existir em uma comunidade ética sob o domínio de Deus. (Ibidem, p. 27).

Cabe a essa altura voltar à pergunta inicial a respeito da abordagem de Arendt em contraste com o que foi até agora explanado. É preciso, portanto, abrir um tópico para estudar as breves considerações da politóloga sobre o mal radical em Origens do Totalitarismo, bem como a sua leitura (e também o seu espanto) sobre a prática da banalidade do mal, desta vez na obra Eichmann em Jerusalém (1964).

\section{ARENDT E SEUS MOVIMENTOS EM TORNO DO CONCEITO DE MAL}

É possível divisar ao menos dois momentos da noção de mal nos textos de Hannah Arendt. Certamente o mal comparece, por um lado, como inevitável ante a narrativa da dominação que é específica do totalitarismo - concepção de regime político que Arendt expõe na esteira de uma sucessão histórico-filosófica que vai do antissemitismo até o imperialismo e termina com uma dominação total. Mas também, por outro lado, tal conceito é identificável desde o subtítulo da análise do caso Eichmann julgado em Jerusalém - o que faz com que o conceito de mal avance até uma perspectiva de banalidade, à banalização da maldade no seio social. Assim, faz-se pertinente analisar o tratamento do mal desde a obra Origens do totalitarismo para compreender primeiramente como esse mal se manifesta histórico-filosoficamente através de regimes políticos e, em seguida, avançar ao segundo conceito.

Como já dito na introdução a este trabalho, a concepção do mal esposada por Arendt num primeiro momento está associada à sua avaliação de que os regimes totalitários têm como característica a transformação do elemento humano em supérfluo ante um regime sustentado por uma ideologia dotada de "supersentido". O cenário é, de fato, distópico, uma vez que se expressa no bojo de certas utopias (sejam elas capitalistas ou socialistas) que, postas em prática, renovam diariamente a insensatez. Ou seja, a lógica da ideologia suplanta qualquer refreamento humanitário, uma vez que canaliza tudo ao seu redor para favorecer a ideia central que guia o regime - a ideologia, sob esse aspecto, é convertida numa superstição ideológica. A centralidade do "supersentido" que dá esteio ao regime precisa disciplinar e tornar coerente a realidade do mundo, que é menos real ou menos coerente que o próprio "supersentido".

Quando passa, então, a vigorar, em nome de ideologias que desejam planificar a natureza humana, um tal centro de onde tudo dimana e para onde tudo reflui, Arendt defende que a tentativa do totalitarismo aqui é mesmo a de experimentar com a natureza humana e buscar alterá-la. Esse afã destruidor torna o impossível possível, ou ao menos busca fazê-lo, o que produz também o impunível e o imperdoável. Esse impossível que passa a se apresentar com a roupagem do possível produz crimes que representam o mal absoluto (impunível, imperdoável). Esse mal, sustenta Arendt em Origens, é distinto daquele mal individual tradicionalmente invocado pela filosofia política: não pode ser 
"compreendido nem explicado pelos motivos malignos do egoísmo, da ganância, da cobiça, do ressentimento, do desejo do poder e da covardia" (ARENDT, 2012, p. 609). Solidariedade e pecado são categorias que já não se aplicam aqui.

Kant comparece nesse cenário, aos olhos de Arendt, como aquele que sentiu necessidade de nominar o mal radical, mas que, sintomaticamente, tratou de racionalizar e categorizar o mal radical dentro de limites possíveis, por não conceber a possibilidade de uma inversão total que tornasse as ações impuníveis e ao mesmo tempo imperdoáveis - Kant exemplificou, assim, com a sua própria teorização sobre o mal, a limitação e perplexidade humana ante uma noção tão absoluta. Isso, por sua vez, deixa sem resposta a compreensão - e aqui Arendt abre as portas para uma perspectiva de investigação política desse mal, a partir dos regimes totalitários - desse sistema político que iguala os seres humanos em seu caráter supérfluo, uma vez considerada a grandiosidade do "supersentido" que embala esses regimes. Arendt vaticina uma abertura virtualmente infinita para que as tentações totalitárias retornem:

Os nazistas e bolchevistas podem estar certos de que as suas fábricas de extermínio, que demonstram a solução mais rápida do problema do excesso de população, das massas economicamente supérfluas e socialmente sem raízes, são ao mesmo tempo uma atração e uma advertência. As soluções totalitárias podem muito bem sobreviver à queda dos regimes totalitários sob a forma de forte tentação que surgirá sempre que pareça impossível aliviar a miséria política, social ou econômica de um modo digno do homem. (Ibidem, 2012, p. 610).

Quer-se enfatizar aqui a dimensão política dessa abordagem do mal em Origens. Nesse aspecto, ela diferirá da abordagem apresentada em Eichmann em Jerusalém - um relato sobre a banalidade do mal, que foi escrito mais de dez anos depois da análise sobre o totalitarismo. É bem conhecida a polêmica maneira segundo a qual Hannah Arendt analisou o réu Adolf Eichmann, enfatizando a mediocridade de um oficial que, naquele momento, representava o julgamento de uma alta autoridade do comando nazista - simbolizava, portanto, a levada do nazismo ao julgo da justiça israelense. E é justamente por conta dessa mediocridade narrada ao longo da obra, bem como dos motivos comezinhos e tacanhas com os quais se constituíram a carreira e as aspirações profissionais do oficial alemão atribuídas a ele por Arendt, que a politóloga enfatiza a discrepância entre o profundo mal manejado por aquele aparato militar do qual Eichmann participava e o caráter simplório do homem ali posto diante do público para julgamento. A banalidade do mal é justamente o gap entre o gênio maligno e o homem terrivelmente comum, medíocre no sentido mais genuíno do termo.

Em Eichmann em Jerusalém Arendt passa a uma tentativa de aspecto sociológico (ou psicossocial) de compreensão do mal. É o mal na forma da inocência de quem o pratica, uma inocência cínica, hipócrita ou até genuína. Mas, certamente, um fenômeno socialmente delimitado, psicologicamente desafiador. $\mathrm{O}$ regime político é menos importante aqui, porque o ângulo de análise é aquele que procura interpretar o indivíduo que comanda uma parte do cenário monstruoso 
do sistema total. Esse indivíduo, com suas peculiaridades biográficas, é tratado como o exemplo de um quadro geral de adaptação preocupantemente tranquila, ou mesmo previsível, das ambições pessoais à bureau-cracia criminosa - alguém, aliás, que afirmava não ter nada contra os judeus (e que Arendt atribui claramente como algo plausível):

Claro, ninguém acreditou nele. O promotor não acreditou, porque não era essa a sua função. O advogado de defesa não lhe prestou atenção porque, ao contrário de Eichmann, ele não estava, aparentemente, interessado em questões de consciência. E os juízes não acreditaram nele, porque eram bons demais e talvez também conscientes demais das bases de sua profissão para chegar a admitir que uma pessoa mediana, "normal", nem burra, nem doutrinada, nem cínica, pudesse ser inteiramente incapaz de distinguir o certo do errado. Eles preferiram tirar das eventuais mentiras a conclusão de que ele era um mentiroso - e deixaram passar o maior desafio moral e mesmo legal de todo o processo. A acusação tinha por base a premissa de que o acusado, como toda "pessoa normal", devia ter consciência da natureza de seus atos, e Eichmann era efetivamente normal na medida em que "não era uma exceção dentro do regime nazista". No entanto, nas condições do Terceiro Reich, só se podia esperar que apenas as "exceções" agissem "normalmente". O cerne dessa questão, tão simples, criou um dilema para os juízes. Dilema que eles não souberam nem resolver, nem evitar. (ARENDT, 1999, p. 38).

Fica claro que a banalidade do mal solapa as bases da normalidade. Inverte a exceção e a regra, o certo e o errado. Isso é ainda mais contundente quando Arendt narra a quase correta exposição feita por Eichmann do princípio moral da ética kantiana, sua tradução do imperativo categórico nos termos de "o que eu quis dizer com minha menção a Kant foi que o princípio de minha vontade deve ser sempre tal que possa se transformar no princípio de leis gerais" (Ibidem, p. 153). Isso, entretanto, não passa sem que Arendt faça uma adaptação da fórmula que, de fato, Eichmann utilizou para as suas ações, qual seja: "aja como se o princípio de suas ações fosse o mesmo do legislador ou da legislação local" (ou ainda, conforme o imperativo categórico do Terceiro Reich, "aja de tal modo que o Führer, se souber de sua atitude, a aprove") (Ibidem).

O diagnóstico de Arendt, portanto, é o de que a identificação moral com o dever, que vai além da lei, e implanta o respeito pela consciência da razão prática (ou seja, algo que se situa como base da possibilidade da lei moral), foi aqui trocada por um respeito identificado com a figura do Führer.

Seja qual for o papel de Kant na formação da mentalidade do "homem comum" da Alemanha, não existe a menor dúvida de que Eichmann efetivamente seguia os preceitos de Kant: uma lei era uma lei, não havia exceções. [...]. Essa atitude intransigente em relação ao desempenho de seus deveres assassinos condenou-o mais do que qualquer outra coisa aos olhos dos juízes, o que era compreensível, mas a seus próprios olhos era exatamente ela que o justificava, assim como antes silenciara a consciência que pudesse lhe 
restar. Sem exceções - essa era a prova de que ele havia agido sempre contra seus "pendores", fossem eles sentimentais ou inspirados por interesse, em prol do cumprimento do "dever". (Ibidem, p. 154).

Arendt, então, associa a postura do condenado ao qual ela assiste como réu de um julgamento à do próprio povo alemão como um todo, enfatizando as inversões dos princípios de ação individual:

Muitos alemães e muitos nazistas, provavelmente a maioria esmagadora deles, deve ter sido tentada a não matar, a não roubar, a não deixar seus vizinhos partirem para a destruição (pois eles sabiam que os judeus estavam sendo transportados para a destruição, é claro, embora muitos possam não ter sabido dos detalhes terríveis), e a não se tornarem cúmplices de todos esses crimes tirando proveito deles. Mas Deus sabe como eles tinham aprendido a resistir à tentação. (Ibidem, p. 167).

O que, entretanto, resulta problemático (e certamente merecedor de ulteriores investigações) é o fato recente de que a historiografia tenha desmentido o retrato de Arendt acerca do criminoso Adolf Eichmann. Isso se apresenta na obra Eichmann before Jerusalem (2015), da pesquisadora Bettina Stangneth. Assim, uma das asserções aqui apresentadas - a de que Eichmann, embora tenha sido um contumaz condutor logístico de exterminações de judeus, não odiasse os judeus e nem compactuasse de uma mais profunda malignidade - cai por terra com o relato de que o próprio Eichmann sustentava uma sincera filiação ao nazismo, tendo, inclusive, buscado articular os nazistas remanescentes no seu período na Argentina.

Cabe, nessa esteira, levantar a questão de se a tese da banalidade do mal resta preservada mesmo quando se descobrem fatos fundamentais da biografia de Eichmann que vão na contramão das teses biográficas defendidas por Hannah Arendt. Mas para isso não há mais espaço neste trabalho, o que o encaminha à sua conclusão.

\section{CONCLUSÃO}

A concepção de mal em Kant, embora paradoxalmente fundamentada no binômio imputabilidade e naturalidade, parece oferecer a Arendt algo de verdadeiramente importante: a responsabilidade individual inescusável. Esse é o ponto central que pode ser absorvido do que Kant concebe como sendo a adoção de máximas imorais que, seja como estiverem explicadas, não estão moralmente desculpadas. Ao agente moral kantiano sempre resta a saída da consciência do dever, o que certamente insere suas considerações sobre o mal no bojo de seus estudos antropológicos e morais - remete à liberdade interna do indivíduo. Sua visão sobre o mal, entretanto, dá elementos demasiado apolíticos para que se possa compreender os fenômenos totalitários: explicação que é efetivamente trabalhada por Arendt (não se deve, é claro, exigir de Kant que ele tivesse orientado sua filosofia do século XVIII para o século XX). 
Kant considera, muito devido à separação clara que estabelece entre o direito e a ética, ou entre uma Doutrina do Direito e uma Doutrina da Virtude, que a temática do mal não se constitui politicamente como uma malignidade ameaçadora. Aliás, nem na ética (em específico, na religião) a malignidade completa do mal radical encontra lugar, porque ela é uma ideia concebível, porém nunca efetivada na prática do ser racional que tem a consciência da lei moral e não tem o poder de efetivamente imiscuir nessa consciência a anti-moralidade, no estilo shakespeariano.

Para o contratualismo clássico, ao qual Kant adere parcialmente, certos aspectos do mal na natureza humana são, em verdade, impulsionadores da política - este é, ao menos, o fio condutor que Kant tenta construir e esclarecer em Ideia de uma história universal de um ponto de vista cosmopolita (1784) com a noção de insociável sociabilidade, apresentada na quarta proposição desta obra. Assim, a madeira retorcida da qual o ser humano é feito coloca-o sempre mais próximo dos demais e desenvolvendo-se ante a comparação invejosa com eles, partindo de uma observável desordem egoística para a efetivação impensada de um desígnio de progresso naturalmente programado. Mal e progresso.

O mal analisado por Hannah Arendt, por sua vez, fornece elementos mais sutis para se pensar como esse fenômeno ocorre no contexto político contemporâneo, tratando-se de uma transformação sistêmica e sistemática, através da técnica, do humano em supérfluo. No limite, a sutileza dessa abordagem dá conta de que os comandantes do poder totalitário tinham a ilusão de, tal como deuses, poder extinguir - na mecânica dos campos de concentração - toda e qualquer espontaneidade, acabar com o possível, o milagre da política, o elemento humano genuíno. Por consequência, aniquilar o sentido mesmo do político.

Sobre essa questão em Arendt, destaca Richard Bernstein:

[...] ao enfatizar o tema da superfluidade e ao retratar a tentativa totalitária de transformar os seres humanos ao eliminar todos os traços de solidariedade, individualidade, natalidade e liberdade, ela [Hannah Arendt] nos ajuda a entender esta nova forma de mal radical. E ela argumenta que, estritamente falando, os "crimes" dos líderes totalitários eram impuníveis e imperdoáveis. (BERNSTEIN, 2002, p. 22). ${ }^{8}$

É verdade que Hannah Arendt é mais eficiente ao concatenar a relação do mal na sua dimensão política em Origens, isto porque em Eichmann em Jerusalém as considerações da culpabilidade entram em cena e a tentativa de construir um prognóstico da agência moral do indivíduo acabam particularizando a mentalidade e a psicologia dos envolvidos na ação política. Essa recaída factual fragiliza seus argumentos, pois eles dependem muito de uma correta compreensão da personalidade de Adolf Eichmann e são, talvez ilegitimamente, generalizados para

\footnotetext{
8 Traduzido pelo autor: "[...] by emphasizing the theme of superfluousness and by depicting the totalitarian attempt to transform human beings by eliminating all traces of solidarity, individuality, natality, and freedom, she [Hannah Arendt] helps us to understand this new form of radical evil. And she argues that, strictly speaking, the "crimes" of totalitarian leaders were unpunishable and unforgivable."
} 
a postura coletiva dos cidadãos alemães ante o Holocausto. Essa constatação preserva, ainda, a primeira concepção de mal discutida por Arendt - a da radicalidade do mal como ameaça de superfluidade do ser humano no interior de uma ideologia dotada de "supersentido".

\section{REFERÊNCIAS BIBLIOGRÁFICAS}

ARENDT, Hannah. Eichmann em Jerusalém - um relato sobre a banalidade do mal. Tradução José Rubens Siqueira. São Paulo: Companhia das Letras, 1999.

Origens do totalitarismo. Tradução Roberto Raposo. São Paulo: Companhia das Letras, 2012.

BERNSTEIN, Richard. Reflections on radical evil: Arendt and Kant. Soundings: An Interdisciplinary Journal, v. 85, n. 1/2, p. 17-30, Spring/Summer 2002. Disponível em: https://www.jstor.org/stable/41179024?seq=1\#page_scan_tab_contents. Acesso em: 03 de junho de 2016.

BORGES, Maria de Lourdes. Para todo mal, a cura. Con-Textos Kantianos: International Journal of Philosophy, n. 1, p. 10-22, Noviembre 2014. Disponível em: $\quad$ http://www.con-textoskantianos.net/index.php/revista/article/view/17. Acesso em: 02 de maio de 2016.

. Passions and evil in Kant's Philosophy. Manuscrito, Campinas, v. 37, n. 2, p. 333-355, jul.-dez. 2014. Disponível em: http://www.scielo.br/scielo.php?script=sci_arttext\&pid=S010060452014000200333. Acesso em: 05 de junho de 2016.

GIACOIA JR, Oswaldo. Reflexões sobre a noção de mal radical. Studia Kantiana, v. $1, \quad$ p. 183-202, 1998.1 Disponível em: http://www.sociedadekant.org/studiakantiana/index.php/sk/article/view/8.

Acesso em: 16 de maio de 2016.

KANT, Immanuel. Antropologia de um ponto de vista pragmático. Tradução Clélia Aparecida Martins. São Paulo: Iluminuras, 2006.

A Religião nos limites da simples razão. Tradução Artur Morão. Lisboa:

Edições 70, 2008.

. Metafísica dos costumes. Tradução Clélia Aparecida (primeira parte), Martins, Bruno Nadai, Diego Kosbiau e Monique Hulshof (segunda parte). Petrópolis: Vozes, 2013.

Ideia de uma história universal de um ponto de vista cosmopolita.

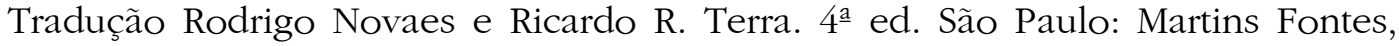
2016.

KLEMME, Heiner. A liberdade do arbítrio e o domínio do mal: a doutrina de Kant do mal radical entre moral, religião e direito. Studia Kantiana, v. 15, p. 5-37, 2013. Disponível em: http://www.sociedadekant.org/studiakantiana/index.php/sk/article/view/146. Acesso em: 16 de maio de 2016.

STANGNETH, Bettina. Eichmann before Jerusalem: the unexamined life of a mass murderer. Translated Ruth Martin. New York: Penguin, 2015. 